Corien Bakermans (Ed.)

Microbial Evolution under Extreme Conditions

Life in Extreme Environments 


\section{Life in Extreme Environments}

Edited by

Dirk Wagner

Volume 2 


\section{Microbial Evolution under Extreme Conditions}


Editor

Corien Bakermans

Altoona College

The Pennsylvania State University

3000 Ivyside Park

Altoona, PA 16601, USA

cub21@psu.edu

ISBN 978-3-11-033506-4

e-ISBN (PDF) 978-3-11-034071-6

e-ISBN (EPUB) 978-3-11-038964-7

ISSN 2197-9227

Library of Congress Cataloging-in-Publication Data

A CIP catalog record for this book has been applied for at the Library of Congress.

Bibliographic information published by the Deutsche Nationalbibliothek The Deutsche Nationalbibliothek lists this publication in the Deutsche Nationalbibliografie; detailed bibliographic data are available on the Internet at http://dnb.dnb.de.

(C) 2015 Walter de Gruyter GmbH, Berlin/Munich/Boston

Typesetting: le-tex publishing services $\mathrm{GmbH}$, Leipzig

Printing and binding: Hubert \& Co. GmbH \& Co. KG, Göttingen

@ Printed on acid-free paper

Printed in Germany

www.degruyter.com 